\title{
SAVANNA WOODLAND SOIL MICROMORPHOLOGY RELATED TO WATER RETENTION
}

\author{
Carlos Eduardo Pinto Juhász'; Miguel Cooper²*; Patrícia Ribeiro Cursi³; André Oppitz Ketzer³; \\ Raul Shiso Toma ${ }^{1}$ \\ ${ }^{1}$ USP/ESALQ - Programa de Pós-Graduação em Solos e Nutrição de Plantas. \\ ${ }^{2}$ USP/ESALQ - Depto. de Ciência do Solo, C.P. 09 - 13418-900 - Piracicaba, SP - Brasil. \\ ${ }^{3}$ USP/ESALQ - Graduando em Engenharia Agronômica. \\ *Corresponding author <mcooper@esalq.usp.br>
}

\begin{abstract}
The limiting factors of the Brazilian savanna physical environment have been largely discussed. Soil morphology is fundamental to understand the behavior of soil water flow, soil physical properties and soil-landscape relationships. The aim of this study is to relate soil micro and macromorphologic attributes to soil water retention on a toposequence under native savanna woodland (cerradão) in a permanent plot of $320 \mathrm{~m} \times 320 \mathrm{~m}$ installed in Assis, SP, Brazil. Samples collected at five points within the toposequence were used to determine the soil macroporosity by means of image analyses, estimated total porosity, chemical analysis, particle size distribution analysis and soil water retention. From the summit down to the footslope, the soils were classified as Rhodic Haplustox, Typic Haplustox and Epiaquic Haplustult, presenting a gradual color transition and a sandy loam texture. In the surface horizons, the higher organic matter content and the high total macroporosity determined a lower soil bulk density and lower water retention. In the Oxisols, the high soil macroporosity results from the packing of microaggregates in the oxic horizon. In the Ultisol, the lower total porosity in the deeper horizons resulted in a higher water retention and an imperfect water drainage. The water retention conditions on the slope influenced the morphological differences in soil color and structure. The low water retention on the surface and oxic horizons, conditioned by the high total macroporosity, is one of the factors that may define the vegetal pattern of the savanna woodland within the permanent plot.
\end{abstract}

Key words: Brazilian savanna, soil porosity, soil water flow, soil physical quality, toposequence

\section{MICROMORFOLOGIA DE SOLO SOB CERRADÃO EM RELAÇÃO À RETENÇÃO DE ÁGUA}

\begin{abstract}
RESUMO: Os fatores limitantes do ambiente físico do Cerrado têm sido muito discutidos. Porém, o detalhamento da morfologia do solo torna-se fundamental à compreensão do seu funcionamento físico-hídrico e sua relação com a paisagem. O objetivo deste estudo foi relacionar os atributos macro e micromorfológicos à retenção de água no solo em uma toposseqüência sob cerradão em uma parcela permanente de $320 \times 320$ m, instalada em Assis, SP. Amostras coletadas em cinco pontos distribuídos na toposseqüência foram utilizadas para determinar a macroporosidade do solo por análise de imagens, porosidade total estimada, análise química, granulometria e retenção de água no solo. De montante a jusante, os solos foram classificados como Latossolo Vermelho, Latossolo Vermelho-Amarelo, Latossolo Amarelo e Gleissolo Háplico, apresentando uma transição gradual de cor e textura franco-arenosa. No horizonte de superfície, o maior teor de matéria orgânica e a elevada macroporosidade total determinaram menor densidade do solo e baixa retenção de água. Nos Latossolos, a microestrutura do solo consistiu principalmente em aglomerados de microagregados, ocasionando uma elevada macroporosidade no horizonte diagnóstico. No Gleissolo, a menor porosidade total nos horizontes mais profundos resultou em uma maior retenção de água e drenagem imperfeita. As diferenças morfológicas de cor e estrutura do solo foram influenciadas pelas condições de retenção de água na vertente. A baixa retenção de água nos horizontes de solo superficiais e latossólicos, condicionada pela elevada macroporosidade total, é um dos fatores que pode definir o padrão vegetacional de cerradão na parcela permanente.

Palavras-chave: Cerrado, porosidade do solo, fluxo de água no solo, qualidade física do solo, toposseqüência
\end{abstract}




\section{INTRODUCTION}

Brazilian savanna is considered as sustaining the greatest biodiversity of the planet (Brasil, 2002). Since 1970, its intense occupation occurred related to technological advances in soil fertility and in the genetic improvement of plants that increased crop productivity in soils of low nutrient availability. This intense agricultural exploitation caused an increasing fragmentation of the savanna biome. In the state of São Paulo, Brazil, for instance, the savanna woodland is considered to be the main savanna physiognomy. Nowadays, this physiognomy is concentrated in priority fragments for the preservation of the savanna biodiversity (Durigan et al., 2003) due to the high anthropic impact (Brasil, 2002). For this reason, detailed studies to provide a better understanding the ecology of this biome are urgent. Priority should be given to studies that emphasize soil physical studies associated to the water availability (Resck, 2002).

Soil morphology, characterized by soil structural analysis in toposequences, facilitates the understanding of the topographic influence on the chemical, physical, hydrological and micromorphological attributes of soils (Cooper et al., 2005; Santos et al., 1998). Micromorphology combined with other soil analyses helps in the integration and synthesis of soil processes, covering several hierarchical levels (Miedema, 1997), from the landscape to the soil microstructure (Castro et al., 2003). Soil-water dynamics plays an important role in the different Brazilian savanna (Cerrado) physiognomies (Oliveira-Filho \& Ratter, 2002), which can be improved by associated geomorphical and pedogenesis studies (Santos et al., 1996; 1998).

This study is attached to the Thematic Project "Diversity, dynamics and preservation in the São Paulo State forests: 40 ha of permanent plots", of the BIOTA/ FAPESP Program and has the purpose of characterizing the soil macro and micromorphology and its influence on the hydrological functioning of soils developed under savanna woodland.

\section{MATERIAL AND METHODS}

The study area is located in Assis, State of São Paulo, Brazil (22 $35^{\prime} \mathrm{S}$ and $50^{\circ} 22^{\prime} \mathrm{W}$ ) (Durigan et al., 1999). The climate is classified, according to Köppen as Cwa, transition to Cfa, mild with a short dry winter and hot summer, with average annual precipitation of $1,468 \mathrm{~mm}$ and annual temperature of $20^{\circ} \mathrm{C}$ (Bologna et al., 2003).

A permanent plot of $320 \mathrm{~m} \times 320 \mathrm{~m}$ was installed in an area with predominant vegetation of sa- vanna woodland (cerradão) with a physiognomy of closed woody vegetation (Oliveira-Filho \& Ratter, 2002), and was subdivided into 256 subplots of $20 \mathrm{~m}$ $\times 20 \mathrm{~m}$. A toposequence was defined inside the permanent plot, representing main types of soil. The distribution of the horizons in the toposequence was made according to the structural analysis technique proposed by Boulet et al. (1982). Five points were selected to open pits, in which the morphological description was carried out according to Lemos \& Santos (2002), the classification of soils according to Embrapa (1999) and the collection of disturbed and undisturbed samples for laboratory analysis.

Micromorphological studies were made to detail soil macroporosity. Undisturbed soil blocks were prepared and impregnated with polyester resin diluted in styrene monomer as suggested by Murphy (1986). A fluorescent pigment was added to this solution to distinguish the pore space from the soil matrix. The shape (irregular, elongated, rounded) and the size (small, medium, large) of pores were defined according to Cooper et al. (2005). The resolution of the images was of $1024 \times 768$ pixels and the microphotographs were obtained with $10 x$ enlarging.

The total porosity was calculated from soil bulk density and particle density. Soil bulk density was obtained from undisturbed soil samples collected in volumetric cores and soil particle density by the volumetric method (EMBRAPA, 1997). The total soil porosity was also estimated in the undisturbed samples from the saturation soil water content, with all pores water filled.

Air-dried fine soil samples were used for chemical and particle-size distribution analyses. The particle-size analysis was carried out using the hydrometer method, as recommended by Camargo et al. (1986). The chemical analysis was restricted to organic matter content, obtained by oxidation with natrium bichromate and colorimetry, according to Cantarella et al. (2001).

The same samples collected for bulk density were used for the establishment of water retention curves. Nine matric potentials were applied to the samples: $1,3,5,8$ and $10 \mathrm{kPa}$, on water tension tables; 33 and $100 \mathrm{kPa}$ in medium pressure chambers; 500 and $1500 \mathrm{kPa}$ in Richard's high pressure chambers, as described by Klute (1986). The gravimetric moisture was obtained after each pressure application, including saturation. The volumetric water content was calculated using respective bulk density values (Juhász et al., 2006). The soil water retention curves were adjusted by the SWRC program (Dourado Neto et al., 2000), to the Van Genuchten 
(1980) model, using the Mualem (1976) restriction. With the parameters of this model it was possible to determine the $\mathrm{S}$ parameter, conceived by Dexter (2004), which indicates the soil physical quality from soil water retention data.

The soil macroporosity was obtained with 14 replicates for samples obtained in a completely randomized design. These results were analyzed using basic descriptive statistical analysis. The relationship between the main variables was established using Pearson's simple correlation coefficient performed in the Statistical Analysis System software package.

\section{RESULTS AND DISCUSSION}

The soils were classified from the summit down to the footslope as Rhodic Haplustox in T1 and T2 profiles; Typical Haplustox in T3 and T4 and Epiaquic Haplustult in T5 (Figure 1). The local relief

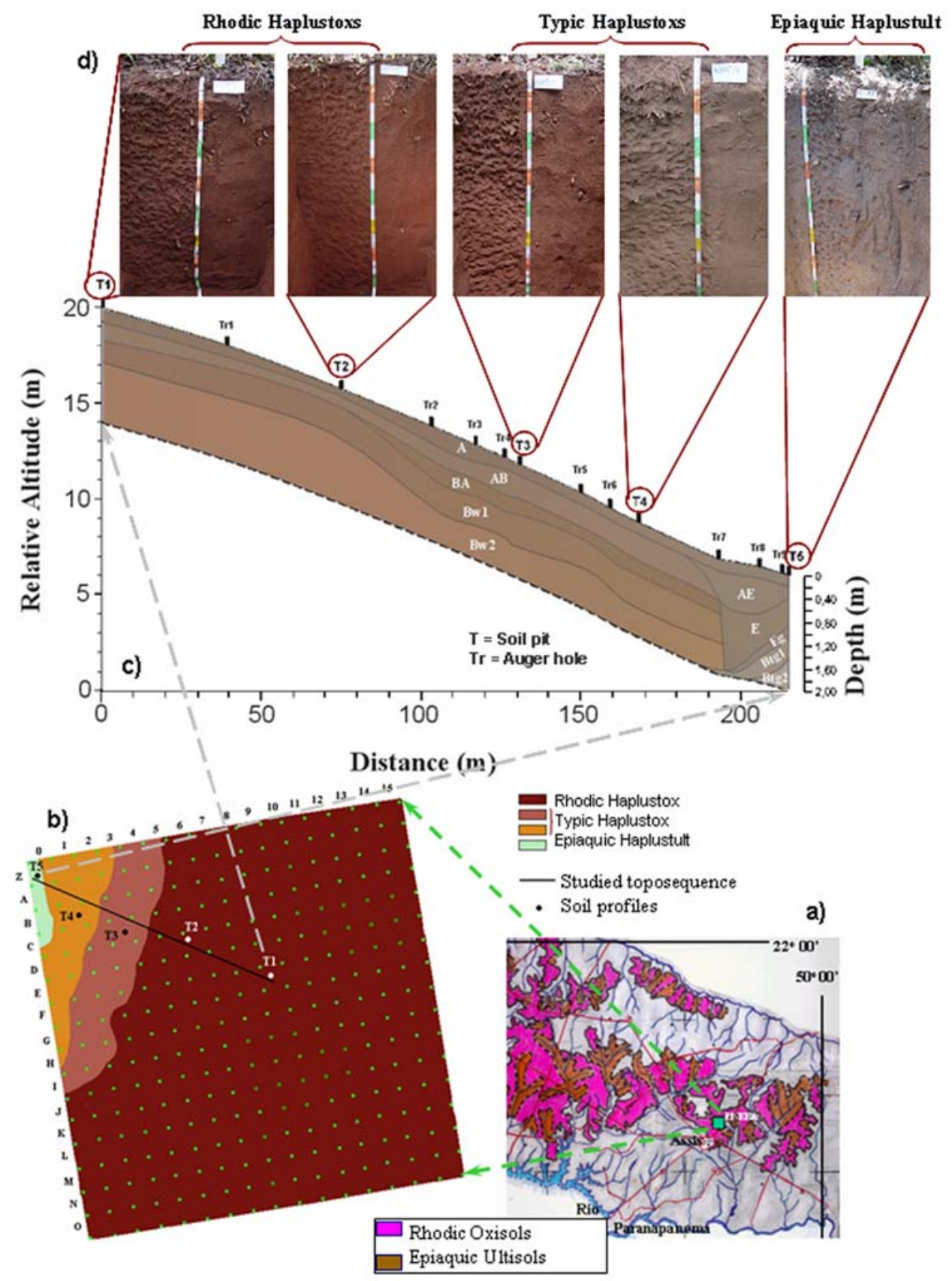

Figure 1 - Hierarchical levels of soil morphology and description. a) Semi-detailed soil map. b) Ultra-detailed soil map. c) Studied toposequence. d) Soil profiles. 
is slightly undulated, with a slope of $0.06 \mathrm{~m} \mathrm{~m}^{-1}$, within the typical slope ranges of Brazilian savanna ecosystems (Resck, 2002). The dystrophic character observed in all the toposequence is common in soils under savanna (Furley \& Ratter, 1988).

The transition between the soil profiles in the toposequence is very homogeneous. There is a gradual color transition from the summit down to the footslope, from the Oxisols (T1 to T4) to the Ultisol (T5), probably related to the landscape position as suggested by Richardson \& Daniels (1993). The Oxisols, located on the summit and backslope, are deep and well drained soils. However, the Ultisol (T5), on the footslope, has an imperfect drainage in the Btg horizon (Figures 1c and 1d), evidenced by the presence of mottles and nodules (Richardson \& Daniels, 1993). This transition from Oxisol to Ultisol was also observed by Salomão \& Queiroz Neto (1996) in Bauru, Western São Paulo plateau. In that same location, Santos et al. (1998) found the occurrence of Rhodic Haplustoxes on the summit with a gradual transition to Typic Haplustoxes on the backslope. These similar situations must occur mainly because of the parent material characteristics, which can be described as sandstones from the Bauru Group with insertions of siltstones and sandstones from the Adamantina Formation (Bologna et al., 2003; Santos et al., 1998). At the semi-detailed scale only Rhodic Haplustox predominates and there is an occurrence of alluvial soils near the watercourses (Figure 1a). However, as the level of detail is increased, more classes and subclasses of soils are recognized (Figure 1b) with their respective transitions (Figure 1c).

The predominant textural class over the whole toposequence is sandy loam. However, A horizons in $\mathrm{T} 1$ and T4 (Oxisols) and A and E in T5 (Ultisol) have a loamy sand textural class, whereas the Btg2 horizon (Ultisol) of T5 is a sandy clay loam. The soil structure in the A horizons presents small weak granular aggregates with exception to T4 where the structure is dominated by small and medium sized granular aggregates. In the oxic horizon, weak subangular blocks dominate, which undo in strong microgranular structure. In the Btg horizon of the Ultisol, the structure is in small to medium sized moderate to strong subangular blocks.

With the aid of micromorphology it is possible to broaden the understanding of the origin and development of soil structure processes (Cooper et al., 2005), facilitating the description of the transitions between soils along the toposequence. However, the image analysis quantifies only macropores and mesopores. According to the classification of Bullock et al. (1985), the mesopores have diameters between $50 \mathrm{~mm}$ and 500 $\mathrm{mm}$ and the macropores, between $500 \mathrm{~mm}$ and 5,000 $\mathrm{mm}$. The proportion of the total area occupied by micropores is negligible.

The variation in numbers of pores (in a logarithmic scale) and the total area occupied by the pores illustrate the changes in the soil horizons microstructure along the toposequence (Figures 2, 3 and 4).

In all soil profiles the complex pores increased in number along depth (except in the Btg2 horizon of the Ultisol), but they decreased in percentage of the total occupied area (Figures 2, 3 and 4). This behavior denotes a looser microstructure in the A horizon (superficial) of these soils, with a greater macroporosity than the subsurface horizons. The complex pores define the structural units of the soil (Ringrose-Voase, 1991). Therefore, in the A horizon, the complex pores represent a single grain microstructure. In the oxic horizons (Figures 2 and 3), the dominant microstructure is microgranular, as observed by Cooper et al. (2005). In the Btg2 horizon (T5), however, a greater amount of large rounded pores occur when compared to the other horizons described. This indicates a greater presence of vughs, probably due to a denser microstructure, with a lower percentage of total area occupied by these pores (Figure 4), and to the presence of nodules and mottles. The elongated pores that generally represent fissures are negligible (less than two percent of total area occupied by the pores) in these soils.

The water conductivity and retention in the soil depend on the pore shape and, consequently, on soil structure. Complex pores, generally, result from the packing of single grains and/or aggregates (RingroseVoase \& Bullock, 1984). These pores favor water infiltration in detriment to retention. As large complex pores predominantly occupy the total area of the pores, the water retention is low in the horizons described in the toposequence, except in Btg2 (Figure 5), in which the presence of vughs leads to an increase in water retention.

In the soil water retention curves (Figure 5), macro and mesopores can be separated from micropores, at the water tension (matric potential) of $6 \mathrm{kPa}$ (Resck, 2002). This value corresponds to a pore diameter of $50 \mathrm{~mm}$, calculated from the theoretical relationship in which the radius of the pores is equal to the matric potential or water suction $(\mathrm{kPa})$ divided by 0.15 , at $20^{\circ} \mathrm{C}$ (Marshall, 1959). Apart from this, the total porosity can be estimated from the soil saturation volumetric water content.

In the surface horizons, there is a larger macro (and meso) porosity, as estimated from the saturation water content, except in the T2 profile, possibly due to methodological failure. Anyway, in the entire sur- 
face, without exception, the slope of the curves with respect to the matric potential axis (Figure 5), represented by the $\mathrm{S}$ parameter (Table 1 ) is steeper, that is, the drainage is excessive and the water is poorly retained. This predominance of vertical water movement and the relation of this behavior to the sandy texture and high macroporosity were also observed by Salomão \& Queiroz Neto (1996) and Santos et al. (1996). Here, this macroporosity was evidenced by the predominance of large complex pores, frequently coalescent, obtained from bidimensional image analysis (Figures 2, 3 and 4).

On the surface, the larger total area occupied by pores and the higher total porosity is due to a sandier texture and also to the higher aggregate stability, caused by a higher organic matter content (Le Bissonais, 1996). In this way, despite the sandier texture, the soil bulk density is lower (Table 1), showing a non-significant correlation between clay and soil bulk density (Table 2). So, the higher organic matter content and the lower soil bulk density indicate that there is a more continuous macropore system under native perennial vegetation, due to the formation of biopores (Salako \& Kirchhof, 2003). The low water retention in the surface horizons, together with the larger organic matter content, causes oscillations in soil moisture, resulting in low water storage for the plants in periods with lack of rain as observed by Juhász et al. (2006).

For the Oxisols (T1 to T4), the oxic horizons represent a lower total porosity as compared to the A horizon (Table 1). When the permanent wilting point $(1,500 \mathrm{kPa})$ is reached, similar values of soil moisture are obtained, in the A horizon, as well as in the oxic horizon (Figure 5). The differences in total porosity

Table 1 - Clay content, organic matter content (OM), soil bulk density (BD), soil particle density (PD), Total porosity (TP) and S (slope) soil physical quality index of the described soil horizons.

\begin{tabular}{|c|c|c|c|c|c|c|c|}
\hline Horizon & Depth & Clay & $\mathrm{OM}$ & $\mathrm{BD}$ & $\mathrm{PD}$ & $\mathrm{TP}$ & $\mathrm{S}$ \\
\hline & $\mathrm{m}$ & $\mathrm{g} \mathrm{kg}^{-1}$ & $\mathrm{~kg} \mathrm{~m}^{-3}$ & $\ldots-\mathrm{t} \mathrm{m}^{-3}$ & - & $\mathrm{m}^{3} \mathrm{~m}^{-3}$ & - \\
\hline \multicolumn{8}{|c|}{ T1 - Rhodic Haplustox } \\
\hline A & $0.00-0.25$ & 120 & 17.7 & 1.26 & 2.67 & 0.53 & 0.096 \\
\hline $\mathrm{AB}$ & $0.25-0.56$ & 143 & 13.0 & 1.46 & 2.74 & 0.47 & 0.077 \\
\hline Bw1 & $0.56-0.94$ & 161 & 11.2 & 1.46 & 2.78 & 0.48 & 0.071 \\
\hline Bw2 & $0.94-1.42+$ & 181 & 10.2 & 1.46 & 2.67 & 0.45 & 0.063 \\
\hline \multicolumn{8}{|c|}{ T2 - Rhodic Haplustox } \\
\hline A & $0.00-0.14$ & 151 & 20.5 & 1.16 & 2.60 & 0.55 & 0.106 \\
\hline $\mathrm{AB}$ & $0.14-0.32$ & 141 & 14.9 & 1.40 & 2.70 & 0.48 & 0.074 \\
\hline Bw1 & $0.32-0.86$ & 161 & 12.1 & 1.52 & 2.60 & 0.42 & 0.065 \\
\hline Bw2 & $0.86-1.42+$ & 171 & 8.4 & 1.50 & 2.50 & 0.40 & 0.080 \\
\hline \multicolumn{8}{|c|}{ T3 - Typic Haplustox } \\
\hline A & $0.00-0.20$ & 151 & 18.6 & 1.21 & 2.94 & 0.59 & 0.112 \\
\hline $\mathrm{AB}$ & $0.20-0.60$ & 151 & 13.0 & 1.41 & 2.63 & 0.46 & 0.083 \\
\hline $\mathrm{BA}$ & $0.60-0.87$ & 171 & 10.2 & 1.46 & 2.63 & 0.45 & 0.064 \\
\hline $\mathrm{Bw}$ & $0.87-1.45+$ & 181 & 9.3 & 1.47 & 2.70 & 0.45 & 0.060 \\
\hline \multicolumn{8}{|c|}{ T4 - Typic Haplustox } \\
\hline A & $0.00-0.20$ & 131 & 17.7 & 1.29 & 2.74 & 0.53 & 0.092 \\
\hline $\mathrm{AB}$ & $0.20-0.66$ & 151 & 13.0 & 1.44 & 2.53 & 0.43 & 0.070 \\
\hline $\mathrm{BA}$ & $0.66-0.93$ & 181 & 11.2 & 1.43 & 2.74 & 0.48 & 0.075 \\
\hline $\mathrm{Bw}$ & $0.93-1.50+$ & 192 & 10.2 & 1.44 & 2.82 & 0.49 & 0.072 \\
\hline \multicolumn{8}{|c|}{ T5 - Epiaquic Haplustult } \\
\hline A & $0.00-0.20$ & 100 & 18.6 & 1.25 & 2.63 & 0.52 & 0.092 \\
\hline $\mathrm{AE}$ & $0.20-0.37$ & 100 & 13.0 & 1.55 & 2.78 & 0.44 & 0.069 \\
\hline E & $0.37-0.80$ & 120 & 10.2 & 1.51 & 2.67 & 0.43 & 0.086 \\
\hline $\mathrm{Eg}$ & $0.80-1.08$ & 140 & 9.3 & 1.51 & 2.74 & 0.45 & 0.074 \\
\hline Btg1 & $1.08-1.38$ & 171 & 9.3 & 1.62 & 2.74 & 0.41 & 0.056 \\
\hline Btg2 & $1.38-1.60+$ & 283 & 8.4 & 1.56 & 2.67 & 0.41 & 0.042 \\
\hline
\end{tabular}


A (0-0.12 m)

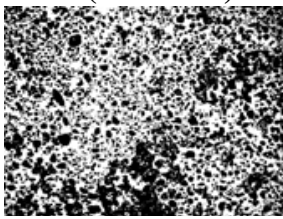

Bw1 (0.64-0.76 m)

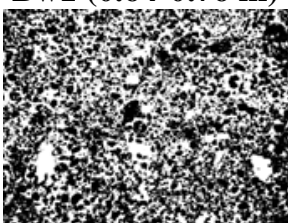

Bw2 (1.20-1.32 m)

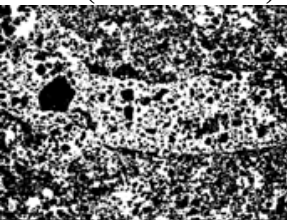

A (0-0.12 m)

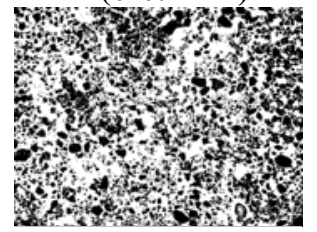

Bw1 (0.50-0.62 m)

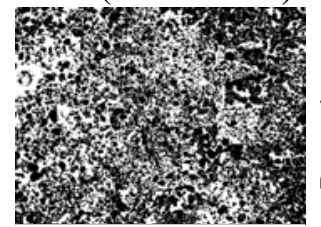

Bw2 (1.10-1.22 m)
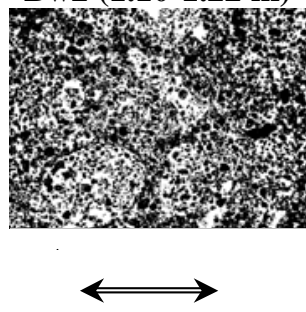

$5000 \mu \mathrm{m}$
T1 - Rhodic Haplustox

Percent of area
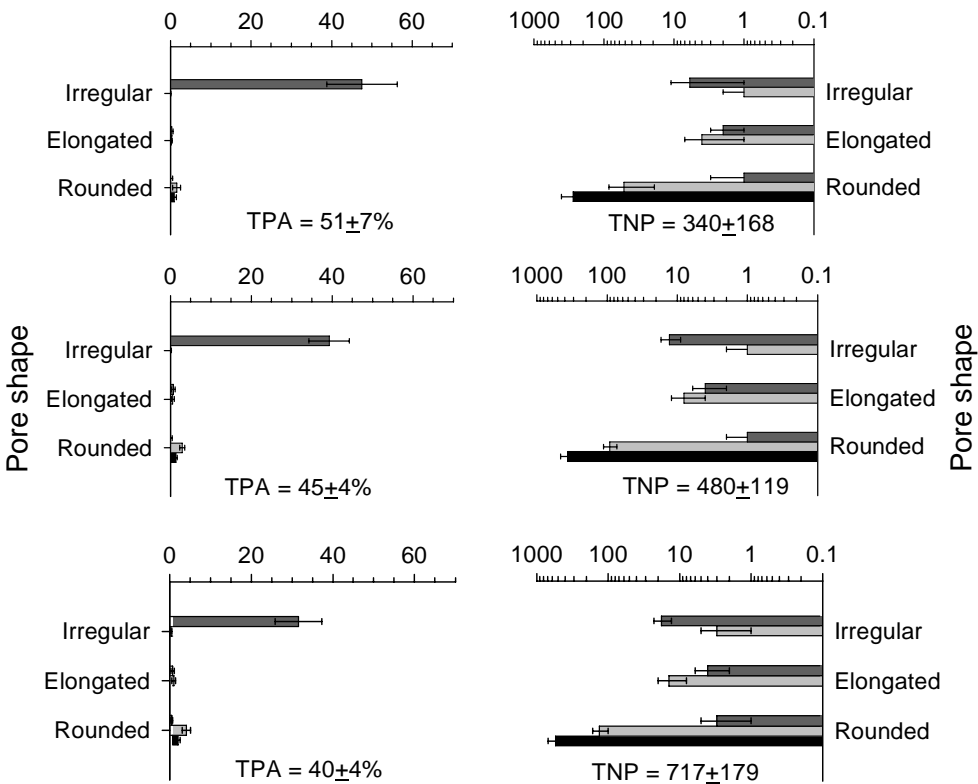

T2 - Rhodic Haplustox

Percent of area Number of pores
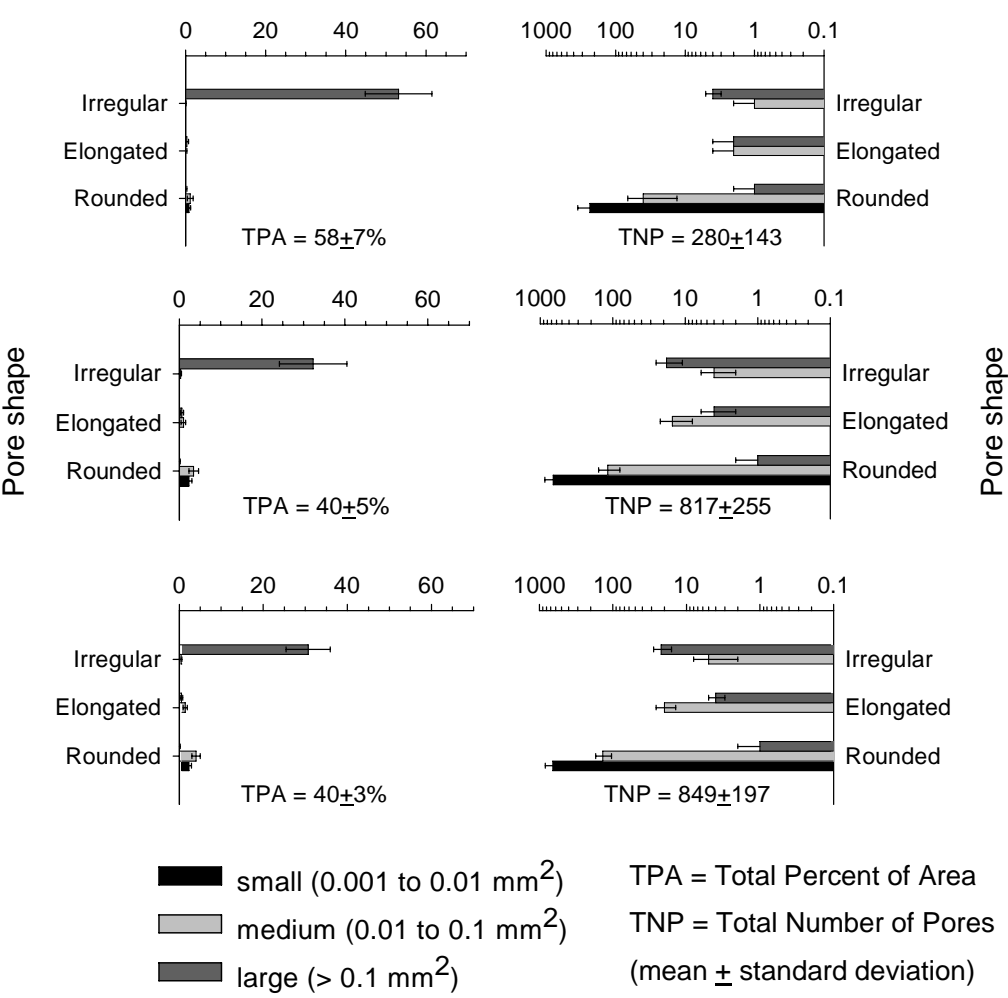

Figure 2 - Microstructure and soil pore distribution in the Rhodic Haplustoxs.

occur because of the decrease in macropores in the oxic horizon in relation to the A horizon. Since for the oxic horizon the slope of the retention curve with respect to the matric potential coordinate (S parameter) is less steep, the quantity of micropores is relatively higher in Bw than in A. This causes a small increment in water retention in the oxic horizon. However, in this horizon, large complex pores predominate, also observed by Santos et al. (1998) who associated this type of pores to the structure formed by microaggregates 
Table 2 - Pearson's correlation of the main soil attributes analyzed.

\begin{tabular}{|c|c|c|c|c|c|c|}
\hline & Clay & $\mathrm{BD}^{\mathrm{a}}$ & $\mathrm{TPA}^{\mathrm{b}}$ & $\mathrm{TP}^{\mathrm{c}}$ & $\mathrm{TPE}^{\mathrm{d}}$ & $\mathrm{OM}^{\mathrm{e}}$ \\
\hline $\mathrm{BD}$ & $0.37^{\text {ns }}$ & & & & & \\
\hline TPA & $-0.78 * *$ & $-0.51 *$ & & & & \\
\hline $\mathrm{TP}$ & $-0.35^{\text {ns }}$ & $-0.92 * *$ & $0.56 * *$ & & & \\
\hline TPE & $-0.24^{\mathrm{ns}}$ & $-0.65 * *$ & $0.21^{\text {ns }}$ & $0.62 * *$ & & \\
\hline OM & $-0.54 * *$ & $-0.90 * *$ & $0.61 * *$ & $0.85 * *$ & $0.52 *$ & \\
\hline$S$ index & $-0.61 * *$ & $-0.86 * *$ & $0.66 * *$ & $0.81 * *$ & $0.59 * *$ & $0.81 * *$ \\
\hline
\end{tabular}

${ }^{\mathrm{a}} \mathrm{BD}=$ soil bulk density; ${ }^{\mathrm{b}} \mathrm{TPA}=$ total percentage of area occupied by the pores; ${ }^{\mathrm{c}} \mathrm{TP}=$ total porosity; ${ }^{\mathrm{d}} \mathrm{TPE}=$ total porosity as estimated from the soil saturation volumetric moisture; ${ }^{*}=P<0.05$; ** $=P<0.01$; ${ }^{\text {ns }}=$ non-significant.

\section{T3 - Typic Haplustox}

$\mathrm{A}(\mathbf{0 - 0 . 1 2} \mathrm{m})$

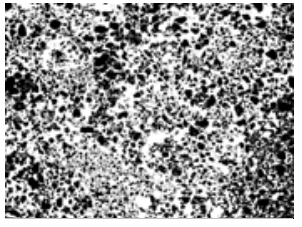

Bw (1.10-1.22 m)

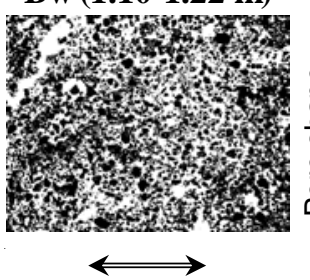

$5000 \mu \mathrm{m}$

A (0-0.12 m)

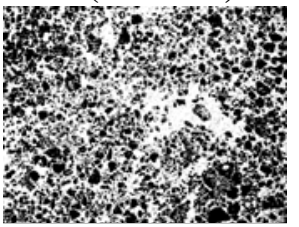

Bw (1.30-1.42 m)
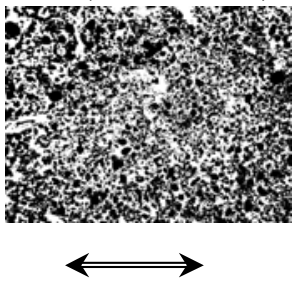

$5000 \mu \mathrm{m}$
Percent of area
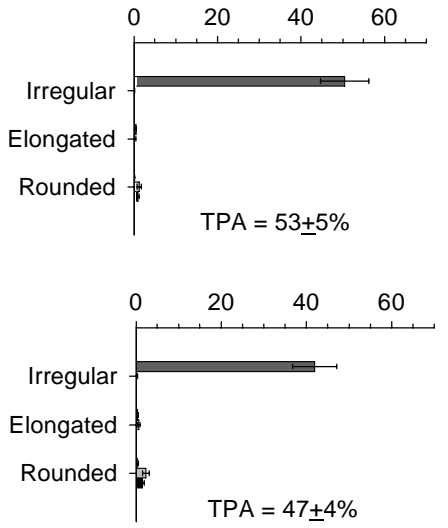

T4 - Typic Haplustox
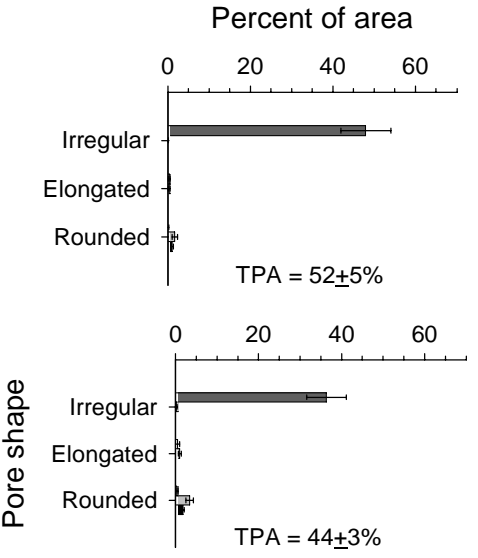

small (0.001 to $0.01 \mathrm{~mm}^{2}$ )
medium (0.01 to $0.1 \mathrm{~mm}^{2}$ )
large (>0.1 $\mathrm{mm}^{2}$ )
Number of pores
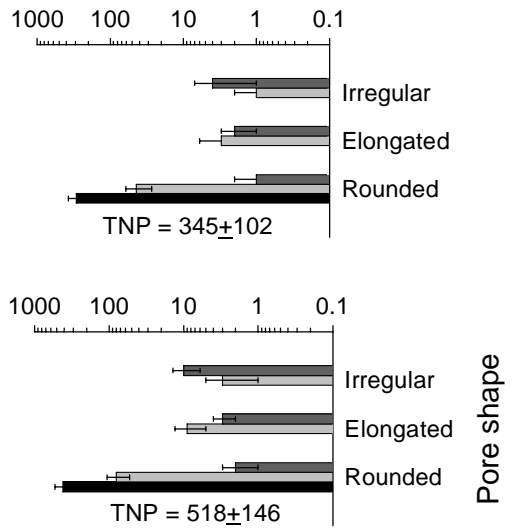

Number of pores
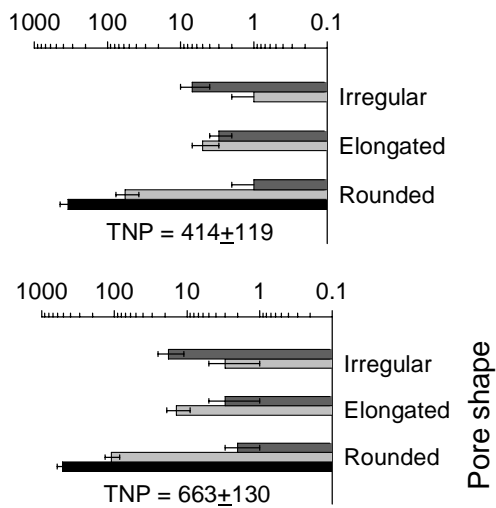

TPA $=$ Total Percent of Area

TNP $=$ Total Number of Pores

(mean + standard deviation)

Figure 3 - Microstructure and soil pore distribution in the Typic Haplustoxs.

and the addition of quartz grains, determining the vertical and deep drainage in Oxisols.

For the Ultisol (T5), the more clayey Btg2 horizon (Table 1) has higher water retention and a higher amount of micropores with respect to the adjacent ho- rizons. This is evidenced by the lower gradient of the water retention curve with respect to the matric potential coordinate (Figure 5) and, consequently, a lower value of $\mathrm{S}$ (Table 1). This reflects the denser structure and the higher values of soil bulk density obtained 


\section{T5 - Epiaquic Haplustult}
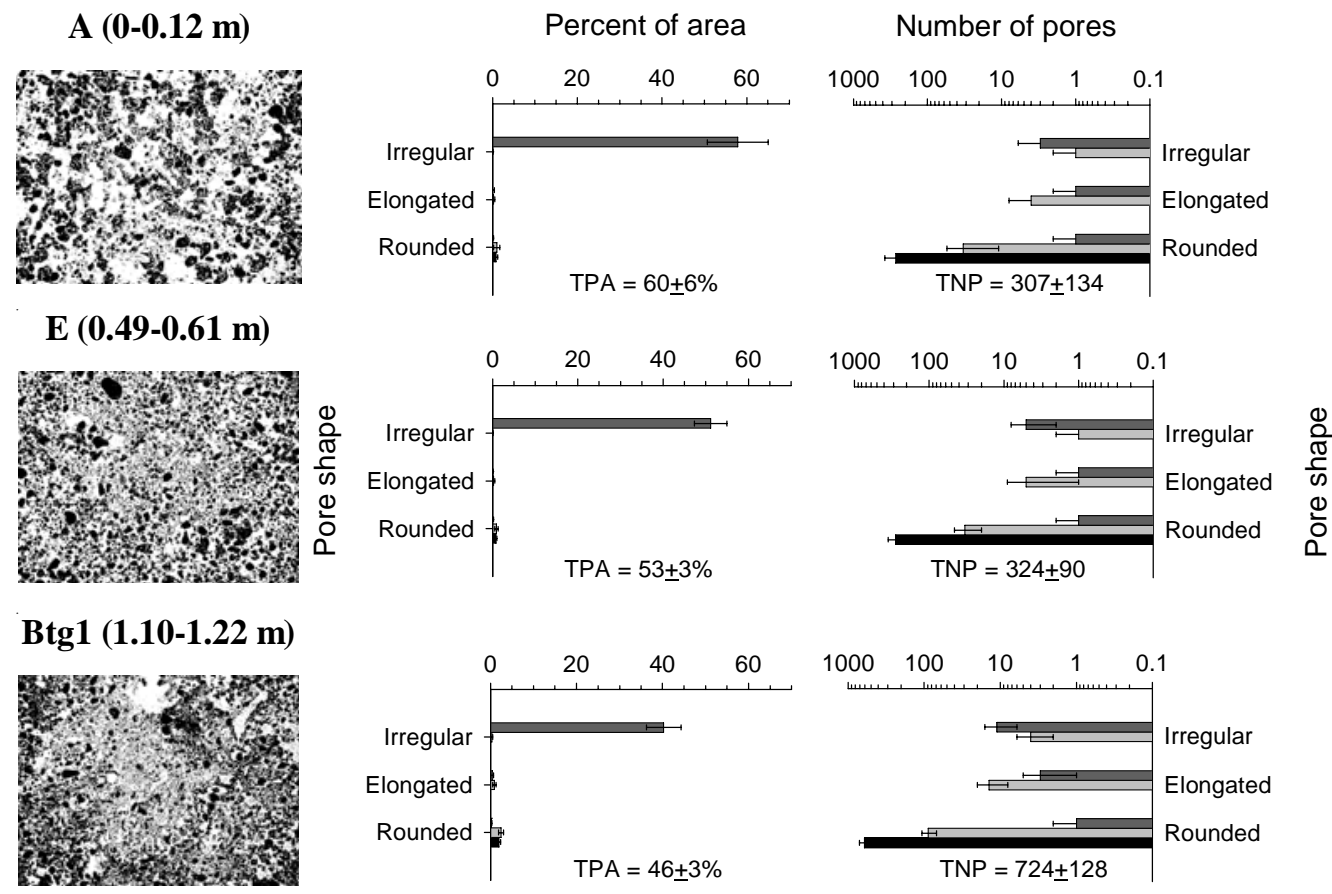

Btg2 (1.40-1.52 m)
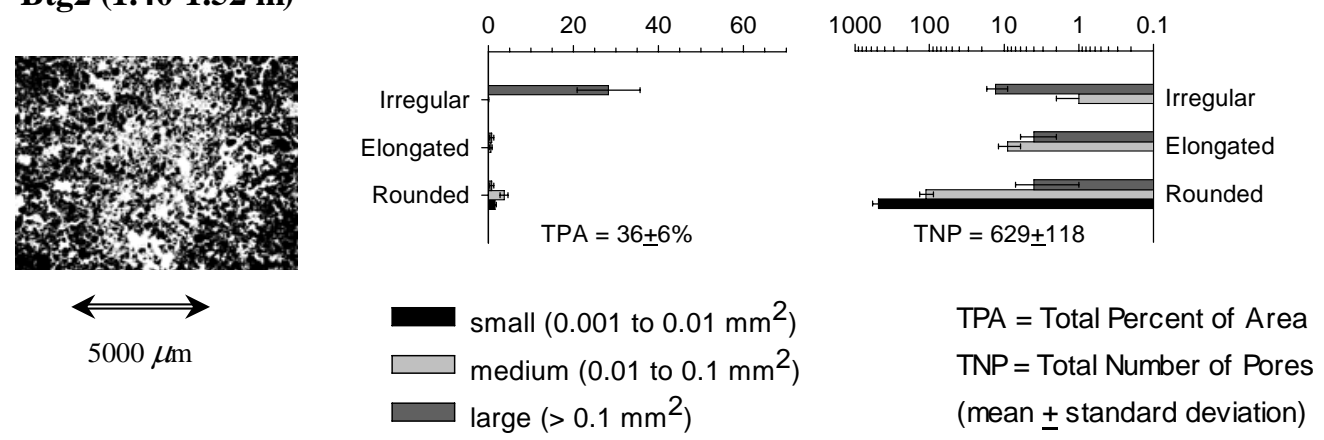

Figure 4 - Microstructure and soil pore distribution in the Epiaquic Haplustult.

for the Btg horizons (Table 1). On the other hand, the high bulk density in the oxic horizons in this toposequence occurs mainly due to the predominant sandy loam textural class, with the quartz grains of the sand fraction exerting an influence on the bulk density. Although the total porosity in Btg (T5) is similar to some oxic horizons, as in $\mathrm{T} 2$, the pore size distribution is different in these horizons. Btg has a higher quantity of micropores whereas the oxic horizon presents a higher content of macropores.

The high total macroporosity, determined by the microstructure of the studied horizons, is also responsible for the high soil hydraulic conductivity, in contrast only to the denser Btg horizon, which had an intermediate hydraulic conductivity as obtained by Juhász et al. (2006). The high hydraulic conductivity in the oxic horizons is evidenced as well by the high amount of pedotubules (biopores) (Glinski \& Lipiec, 1990) like the one examined in the binary image of Bw2 horizon in T1 (Figure 2).

The percentage of total area occupied by the pores (TPA) was inversely proportional to soil density $(P<0.05)$, evidencing the influence of the macroporosity on soil bulk density. This is better understood by the correlation between the soil bulk density and the total porosity as estimated from the soil saturation volumetric moisture (TPE) $(P<0.01)$ (Table $2)$. TPA was also proportional to the organic matter content $(P<0.01)$, showing the ability of the organic matter to increase the aggregate stability and the development of macropores. And, there was an inverse relationship between clay content and the total occupied area by macro and mesopores $(P<0.01)$ (Table 2). 

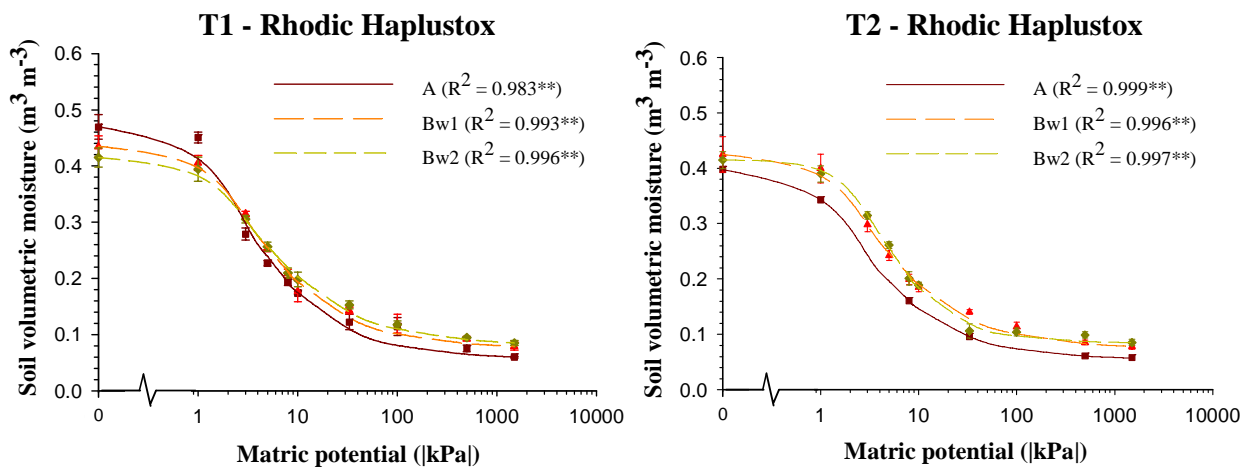

T3 - Typic Haplustox
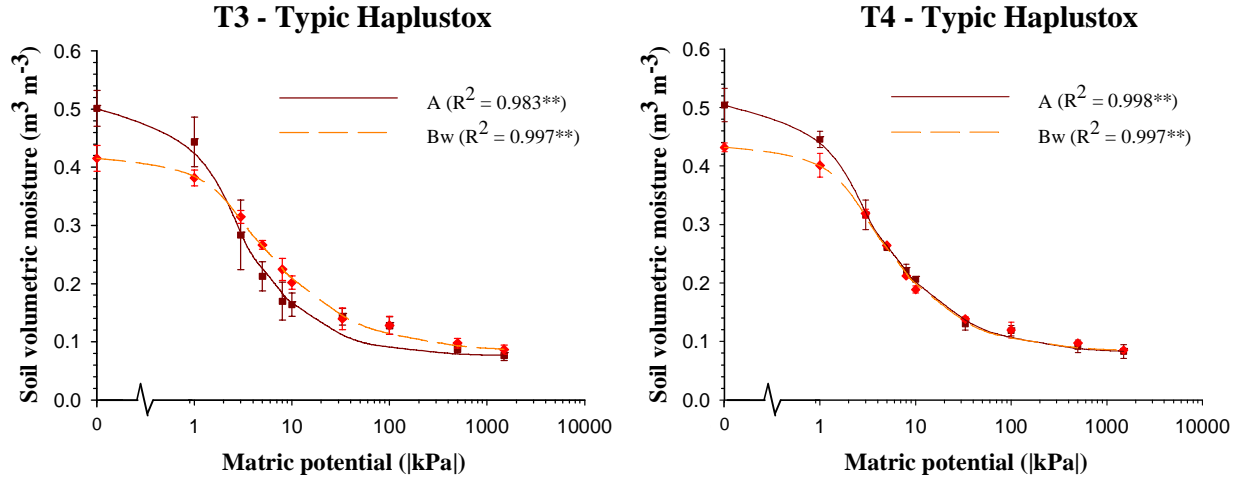

T5 - Epiaquic Haplustult

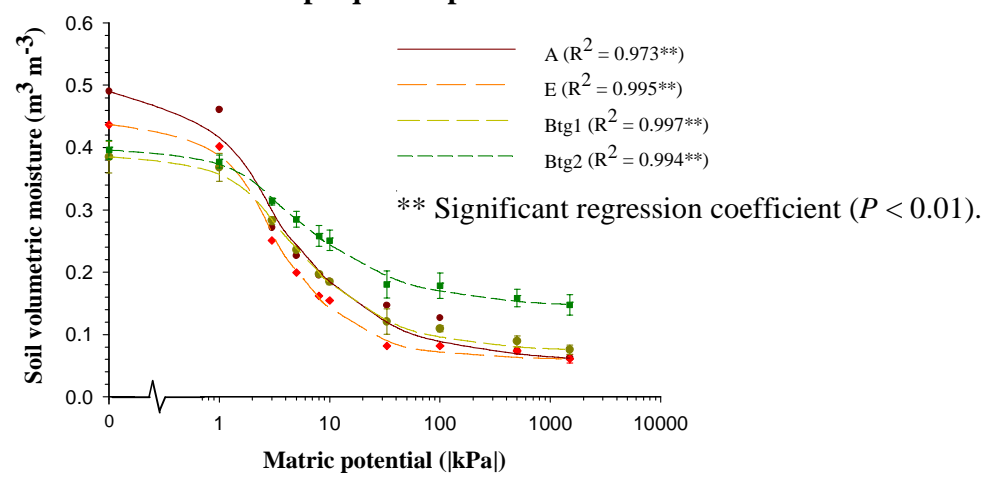

Figure 5 - Soil water retention curves of superficial and diagnostic horizons.

The S parameter determines the physical quality of the soil structure, influenced directly by water retention (Dexter, 2004). The values of S presented in Table 1 show that none of the described horizons presented physical restrictions for the development of roots. However, the Btg2 horizon of the Ultisol is at the limit of good soil physical quality, defined as $\mathrm{S}$ equal to 0.035 by Dexter (2004). Nevertheless, the S parameter describes the physical quality of managed soils. Consequently, more detailed studies are necessary to define tolerable $\mathrm{S}$ values in soils developed under native vegetation.

The S parameter presented a significant correlation $(P<0.01)$ with all soil attributes (Table 2$)$.
The use of quantitative micromorphological studies helps to establish relations between soil structure and the size and distribution of pores with the water retention characteristics of the various soil horizons (Miedema, 1997). The positive correlation between $S$ and TPA $(P<0.01)$ is an example of how different methodologies can be used to analyze related parameters, thus defining the relation between soil functioning and the structural conditions of the soil. Due to the high correlations obtained, it is possible to make extrapolations of this parameter using pedotransfer functions (PTFs). The attributes of these functions should be significantly correlated to the S parameter. 
The overall good soil physical quality indicated by the $\mathrm{S}$ parameter suggests that these soils have no physical obstruction for a good root development. The soil-water dynamics in this site is directly associated to rainfall events with small variations in the mean soil moisture between seasons (Juhász et al., 2006). The lack of rain during the dry season (March to October) interrupts the water dynamics related to rainfall events diminishing the availability of water for the vegetation. This water deficit during the dry season associated to low soil fertility, good root growth conditions and well drained soils are conditions that, according to Oliveira-Filho \& Ratter (2002), are characteristic of dystrophic facies of the savanna woodland.

The study of toposequences makes it possible to carry out data extrapolations to adjacent areas and to detail transitions between soils not recognized in larger scale soil maps. The relations between soil, landscape and vegetation are more easily understood when vegetation and soil maps are superimposed. The evolution or the disappearing of native savanna vegetation fragments, for example, is monitored from the interpretation of satellite images (Durigan et al., 2003). This monitoring helps in the establishment or restoration of native vegetation corridors that aim to preserve the natural biodiversity of a region (Brasil, 2002). For this purpose, it is very important to know the structure and functioning of the soil where one wishes to restore the native vegetation.

The lack of information about the relations between the physical and the biotic environments of the main biomes that cover the state of São Paulo will be eased with the introduction of a data bank created from the thematic project to which this work is attached. This data bank includes phytosociological studies of the vegetation as well as physical, chemical and biological studies of the soils. The detailing in soil attributes carried out in this study may be correlated to vegetation parameters measured within the permanent plot.

\section{CONCLUSIONS}

The morphological characterization of the toposequence soils shows gradual vertical and lateral transitions between the horizons of the soil profiles, mainly regarding their color and structure. The study in toposequence facilitates the understanding of the soil morphology and its physical and hydrological functioning. Soil micromorphology, together with the S parameter, are efficient in the definition and the prediction of the physical, hydrological and structural conditions of the soil. The predominant high total macroporosity and sandy loam texture explain the strongly drained sites on the toposequence, indicating that soil-water dynamics plays an important role in the establishment of savanna woodland.

\section{ACKNOWLEDGEMENTS}

To FAPESP for the scholarships of Carlos E. P. Juhász (Project 04/04799-4) and Patricia R. Cursi (Project 04/08374-8) and financial support (Project 99/ 09635-0) by the BIOTA/FAPESP Program - The Virtual Institute of Biodiversity. To CNPq for the research scholarship of Miguel Cooper. To Rodrigo Chiara Olsen, Thalita Campos Oliveira, José Eduardo Soria e Dorival Grisotto for assistance.

\section{REFERENCES}

BOLOGNA, I.A.; PRADO, H.; MENK, J.R.F.; JOAQUIM, A.C.; LEPSCH, I.F. Levantamento pedológico semidetalhado do Estado de São Paulo: quadrícula de Assis. II. Memorial descritivo. Campinas: Instituto Agronômico de Campinas, 2003. 54p. (Boletim Científico, Série Pesquisa APTA, 8).

BOULET, R.; CHAUVEL, A.; HUMBEL, F.X.; LUCAS, Y. Analyse structurale et cartographie en pédologie: I - Prise en compte de l'organisation bidimensionelle de la couverture pédologique: les études de toposéquences et leurs principaux apports à la connaissance dês sols. Cahiers ORSTOM, Série Pédologie, v.19, p.309-321, 1982.

BULLOCK, P.; FEDOROFF, N.; JONGERIUS, A.; STOOPS, G.; TURSINA, T. Handbook for soil thin section description. Wolverhampton: Waine Research Publications, 1985. 153p.

BRASIL. Ministério do Meio Ambiente. Biodiversidade brasileira: avaliação e identificação de áreas e ações prioritárias para conservação, utilização sustentável e repartição dos benefícios da biodiversidade nos biomas brasileiros. Brasília: MMA, PROBIO, 2002. 404p. (Série Biodiversidade, 5).

CAMARGO, O.A.; MONIZ, A.C.; JORGE, J.A.; VALADARES, J.M.A.S. Métodos de análise química, mineralógica e física de solos do Instituto Agronômico de Campinas. Campinas: IAC, 1986. 94p. (Boletim Técnico, 106).

CANTARELLA, H.; QUAGGIO, J.A.; RAIJ, B. van. Determinação da matéria orgânica. In: RAIJ, B. van; ANDRADE, J.C.; CANTARELLA, H.; QUAGGIO, J.A. (Ed.). Análise química para avaliação da fertilidade de solos tropicais. Campinas: IAC, 2001. cap.9, p.173-180.

CASTRO, S.S.; COOPER, M.; SANTOS, M.C.; VIDAL TORRADO, P. Micromorfologia do solo: bases e aplicações. Tópicos em Ciência do Solo, v.3, p.107-164, 2003.

COOPER, M.; VIDAL-TORRADO, P.; CHAPLOT, V. Origin of microaggregates in soils with ferralic horizons. Scientia Agricola, v.62, p.256-263, 2005.

DEXTER, A.R. Soil physical quality. Part I. Theory, effects of soil texture, density, and organic matter, and effects on root growth. Geoderma, v.120, p.201-214, 2004.

DOURADO NETO, D.; NIELSEN, D.R.; HOPMANS, J.W.; REICHARDT, K.; BACCHI, O.O.S. Software to model soil water retention curves (SWRC, version 2.00). Scientia Agricola, v.57, p.191-192, 2000.

DURIGAN, G.; BACIC, M.C.; FRANCO, G.A.D.C.; SIQUEIRA, M.F. Inventário florístico do cerrado na Estação Ecológica de Assis, SP. Hoehnea, v.26, p.149-172, 1999.

DURIGAN, G.; SIQUEIRA, M.F.; FRANCO, G.A.D.C.; BRIDGEWATER, S.; RATTER, J.A. The vegetation of priority areas for cerrado conservation in São Paulo state, Brazil. Edinburgh Journal of Botany, v.60, p.217-241, 2003. 
EMPRESA BRASILEIRA DE PESQUISA AGROPECUÁRIA. Centro Nacional de Pesquisa de Solos. Manual de métodos de análise de solo. 2.ed. Rio de Janeiro: EMBRAPA, CNPS, 1997. 212p.

EMPRESA BRASILEIRA DE PESQUISA AGROPECUÁRIA. Centro Nacional de Pesquisa de Solos. Sistema brasileiro de classificação de Solos. Brasília: Embrapa Produção da Informação, 1999. 412p.

FURLEY, P.A.; RATTER, J.A. Soil resources and plant communities of the central Brazilian cerrado and their development. Journal of Biogeography, v.15, p.97-108, 1988.

GLINSKI, J.; LIPIEC, J. Soil physical conditions and plant roots. Boca Raton: CRC Press, 1990. 250p.

JUHÁSZ, C.E.P.; CURSI, P.R.; COOPER, M.; OLIVEIRA, T.C.; RODRIGUES, R.R. Dinâmica físico-hídrica de uma toposseqüência de solos sob savana florestada (cerradão) em Assis, SP. Revista Brasileira de Ciência do Solo, v.30, p.401412, 2006.

KLUTE, A. Methods of soil analysis. 2.ed. Madison: SSSA, 1986. pt.1: Physical and mineralogical methods, cap.26, p.635-662: Water retention: laboratory methods. (SSSA. Agronomy, 9).

LE BISSONAIS, Y. Soil characteristics and aggregate stability. In: AGASSI, M. (Ed.). Soil erosion, conservation and rehabilitation. New York: Marcel Dekker, 1996. cap.3, p.4160 .

LEMOS, R.C.; SANTOS, R.D. Manual de descrição e coleta de solo no campo. 4.ed. Viçosa: SBCS, 2002. 83p.

MARSHALL, T.J. Relations between water and soil. Farnham Royal: CAB, 1959. 91p. (Technical Communication, 50).

MIEDEMA, R. Application of micromorphology of relevance to agronomy. Advances in Agronomy, v.59, p.119-169, 1997.

MUALEM, Y. A new model for predicting the hydraulic conductivity of unsaturated porous media. Water Resources Research, v.12, p.513-522, 1976.

MURPHY, C.P. Thin section preparation of soils and sediments. Berkhamsted: A.B. Academic Publications, 1986. 149p.

OLIVEIRA-FILHO, A.T.; RATTER, J.A. Vegetation physiognomies and woody flora of the Cerrado biome. In: OLIVEIRA, P.S.; MARQUIS (Ed.) The cerrados of Brazil: ecology and natural history of a neotropical savanna. New York: Columbia University, 2002. p.91-120.
RESCK, D.V.S. Perspectivas do uso e manejo dos solos no Cerrado. In: ARAÚJO, Q.R. (Org.). 500 anos de uso do solo no Brasil. Ilhéus: Editus, 2002. p.218-237.

RICHARDSON, J.J.; DANIELS, R.B. Stratigraphic and hydraulic influences on soil color development. In: BIGHAM, J.M.; CIOLKOSZ, E.J. (Ed.). Soil color. Madison: SSSA, 1993. p.109125. (Special Publication, 31).

RINGROSE-VOASE, A.J. Micromorphology of soil structure: description, quantification, application. Australian Journal of Soil Research, v.29, p.777-813, 1991.

RINGROSE-VOASE, A.J.; BULLOCK, P. The automatic recognition and measurement of soil pore types by image analysis and computer programs. Journal of Soil Science, v.35, p.673684,1984

SALAKO, F.K.; KIRCHHOF, G. Field hydraulic properties of an Alfisol under various fallow systems in southwestern Nigeria. Soil Use and Management, v.19, p.340-346, 2003.

SALOMÃO, F.X.T.; QUEIROZ NETO, J.P. Dinâmica hídrica dos solos de Bauru (São Paulo-Brasil) aplicada ao manejo. In: CONGRESSO LATINOAMERICANO DE CIÊNCIA DO SOLO, 13., Águas de Lindóia, 1996. Anais. Águas de Lindóia: SBCS: Sociedade Latinoamericana de Ciência do Solo, 1996. 1 CDROM.

SANTOS, L.J.C.; CASTRO, S.S.; SALOMÃO, F.X.T. Organizações micromorfológicas e sua relação com a circulação hídrica: o exemplo de Bauru (SP). In: CONGRESSO LATINOAMERICANO DE CIÊNCIA DO SOLO, 13., Águas de Lindóia, 1996. Anais. Águas de Lindóia: SBCS: Sociedade Latinoamericana de Ciência do Solo, 1996. 1 CD-ROM.

SANTOS, L.J.C.; GRIMALDI, M.; CURMI, P.; HALLAIRE, V.; CASTRO, S.S. Comportement hydrodynamique de sols sur grès au Brésil: conséquences sur la pédogenèse et le relief. In: WORLD CONGRESS OF SOIL SCIENCE, 16., Montpellier, 1998. Proceedings. Montpellier: International Soil Science Society, 1998. 1 CD-ROM.

VAN GENUCHTEN, M.T. A closed-form equation for predicting the hydraulic conductivity of unsaturated soils. Soil Science Society of America Journal, v.44, p.892-898, 1980.

Received October 17, 2006

Accepted May 08, 2007 